\title{
Economic Impacts of Climate Change in Italy and the Mediterranean: Updating the Evidence
}

\author{
Marzio Galeotti ${ }^{1} \&$ Roberto Roson ${ }^{2}$ \\ ${ }^{1}$ University of Milan and IEFE-Bocconi, Italy \\ ${ }^{2}$ Ca' Foscari University, Venice, IEFE-Bocconi and CMCC, Italy \\ Correspondence: Roberto Roson, Dipartimento di Economia, Università Ca'Foscari, Cannaregio 873, 30121, \\ Venezia, Italy. Tel: 39-041-234-9147. E-mail: roson@unive.it
}

Received: March 14, 2012 Accepted: April 16, 2012 Online Published: May 1, 2012

doi:10.5539/jsd.v5n5p27 URL: http://dx.doi.org/10.5539/jsd.v5n5p27

JEL Codes: C68, D58, F43, F47, Q54, Q56

\begin{abstract}
This study presents new estimates of economic impacts of climate change for Italy and other countries, obtained with a full-fledged Integrated Assessment Model (ENVISAGE), developed at the World Bank. This model is qualitatively superior to other models used in the past for the same purpose. It is found out that climate change is expected to reduce the Italian GDP in 2050 , with respect to a reference baseline, by $-0.31 \%$. This figure is about two times higher than previous estimates. Declining tourism demand is the main driver of negative effects on GDP, as Italy would become less attractive as a tourist destination. By the end of the century, however, Italy would also experience severe losses in agricultural production, due to increased temperature and reduced water availability. Even if Italy will notably be affected by climate change, in the absence of any mitigation or adaptation effort, other countries in the Mediterranean will experience larger economic impacts. This is the case of Spain and Middle East - North Africa.
\end{abstract}

Keywords: climate change, integrated assessment, dynamic general equilibrium, Italy, Mediterranean

\section{Introduction and Motivation}

Understanding the nature and consequences of climate change is at the basis of any serious mitigation or adaptation policy. Mitigation means curbing climate change, whereas adaptation means reducing the costs of climate change. In both cases, it is important to assess what would be the costs of inaction, that is, the economic impact of climate change in a baseline scenario, in which no policies are implemented.

Avoiding the environmental and socio-economic damages on human health and welfare is the ultimate justification of more stringent climate policies. The knowledge, as precise as possible, of the monetary benefits associated with avoiding those damages indeed provides one of the crucial elements, together with costs, of the climate policy equation. This task has been keeping environmental economists quite busy in developing appropriate methodologies, producing the necessary data, and designing and simulating suitable climate-economy models. As documented in the contribution of Working Group II (WGII) to the last IPCC Fourth Assessment Report (AR4) (Parry et al., 2007), the state of the art is nowadays represented by soft-linking simulation models of the evolution of global climate, the physical impacts of climate alterations, and the translation of those impacts into socio-economic consequences, expressed in monetary terms.

In this context, it is important to understand that climate change will produce very different effects in several dimensions (sea level rise, tourism, etc.), and each effect should be separately addressed and modelled in a comprehensive framework. Furthermore, climate change will bring about very different (sometimes positive) impacts in various regions and economic sectors. To capture this, an integrated assessment model should combine a systemic approach with a sufficiently high level of disaggregation.

One of the chapters of the WGII volume of the IPCC AR4 was devoted to Europe, for the first time documenting a wide range of climate impacts for the "old continent". Climate change is expected to pose challenges to many European economic sectors and to alter the distribution of economic activity. Table 1 reproduces one of the 
original AR4 tables, providing an overview of the different impacts, their presumed strength and the regional relevance.

Table 1. Summary of main impacts of climate change in Europe (from Parry et al., 2007)

\begin{tabular}{|c|c|c|c|c|c|c|}
\hline $\begin{array}{l}\text { Sectors and } \\
\text { Buctoms }\end{array}$ & Inpast & Morth & Atiantio & $\begin{array}{c}\text { Aros } \\
\text { Eontral }\end{array}$ & Moditor. & Enst \\
\hline \multirow{3}{*}{ Water resourons } & Floods & $\$$ & 4 & $\$$ & + & $\$ 4$ \\
\hline & Water avalatility & $\uparrow \uparrow$ & $1+$ & 4 & 44 & 44 \\
\hline & Water strans & $\dagger+$ & tt & 4 & $\$ 4$ & $\$$ \\
\hline \multirow{8}{*}{$\begin{array}{l}\text { Coastal and } \\
\text { marlhe systems }\end{array}$} & Boach, dune lowlying coast erodiond "coastal squesed" & $\$ \downarrow \downarrow$ & $\$ \downarrow \downarrow$ & na & $\downarrow \downarrow$ & 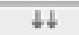 \\
\hline & SLR and surpo-driven flooding & $\$ 4$ & $\$ 4$ & nat & $\$$ & $\$ 4 \$$ \\
\hline & Piver sedinent suppty lo estuarks and dellas & $\$$ & $\downarrow$ & na & $\$ 4$ & + \\
\hline & Sulwater intruskon to aquilers & 4 & 4 & na & 4 & + \\
\hline & Northward migration of marine bioth & $\uparrow$ & ttt & na & $\uparrow$ & $\uparrow$ \\
\hline & Rleing SST, eutrophieason and shoss on blosyetems & 44 & 44 & na & 4 & 4 \\
\hline & Development of ICZM & $\uparrow$ & +4 & na & tt & + \\
\hline & Doepening and lapes inshore waters & t+ & + & na & + & tt \\
\hline \multirow{5}{*}{$\begin{array}{l}\text { Mountalns, } \\
\text { cryosphare }\end{array}$} & Clacler retreat & \$4 & 4 & 44 & $4+4$ & $\$ 44$ \\
\hline & Duration of anow cover & $\$ \$$ & 44 & $\$ 4$ & $\$+\downarrow$ & $\$ 4$ \\
\hline & Pemafrost retreat & $\$ 4$ & $\downarrow$ & 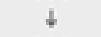 & $\mathrm{na}$ & + \\
\hline & Thes lines upward shif & $t+t$ & ttt & $t+t$ & $\uparrow$ & $t+\uparrow$ \\
\hline & Whal spectes boses & $\$ 4$ & $4+4$ & $\$ 4$ & $4+4$ & $4+4$ \\
\hline \multirow{6}{*}{$\begin{array}{l}\text { Forest, } \\
\text { shrublands and } \\
\text { grasslands }\end{array}$} & Fonest WPP & $\uparrow t$ & 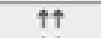 & $+10+$ & 4 & $+10 \div$ \\
\hline & Mortheard/nind thit of tres spechs & $1+1$ & $\uparrow \uparrow$ & t个 & t to & $\$$ \\
\hline & Stablity of forest ecosytems & 4 & 4 & 4 & $4+4$ & $\$ 4$ \\
\hline & Shublands NPP & 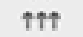 & ttt & 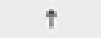 & $\$ 4$ & 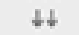 \\
\hline & Natural disturtances (e-9., fire pests, whd-stomn & + & + & 4 & $\$ 4$ & 4 \\
\hline & Grasslanth NPP & $\uparrow+1$ & +1 & + to 4 & 444 & $\uparrow$ \\
\hline \multirow{4}{*}{$\begin{array}{l}\text { Wotlands and } \\
\text { aquatio } \\
\text { ecosysterns }\end{array}$} & Dryingtranstomstion of wetlands & $4+$ & + & + & $4+4$ & $\$ 4$ \\
\hline & Spocles dversity & t to 1 & + & 7 & $\$$ & $\downarrow$ \\
\hline & Eutrophication & + & H & 4 & $\$ 4$ & + \\
\hline & Disturbance of dnined peatlunds & $\$ 4$ & + & $4+$ & na & $\$ 44$ \\
\hline \multirow{6}{*}{ Bodwersty } & Plants & $\$$ & 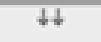 & $\$+4(M t)$ & $4 \$ 4$ & $\downarrow$ \\
\hline & Amphiblans & $\$+$ & $\#$ & tt & $\begin{array}{c}44+(5 W) \\
++(56)\end{array}$ & t1t \\
\hline & Roptlos & $4+$ & $\$ 4$ & $\uparrow \uparrow$ & $4+4 \mathrm{SW}$ & १† \\
\hline & Marine mammals & $\$ \psi$ & $\eta$ & na & $\begin{array}{c}++f(B A) \\
+4 t\end{array}$ & 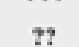 \\
\hline & Low-lying coustal bids & $\$ 4$ & $\ddot{+4}$ & na & $\$ 4$ & 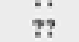 \\
\hline & Freshavater biodversity & $+10+$ & $\mathrm{T}$ & 77 & $\$ 44$ & $m$ \\
\hline \multirow{8}{*}{$\begin{array}{l}\text { Agrkulfure and } \\
\text { tishorks }\end{array}$} & Sutablo cropping area & T†т & $T t$ & 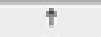 & +4 & 4 \\
\hline & Agrkcultural kand aroa & 44 & 44 & 44 & 44 & 44 \\
\hline & Summer cicos imabs, sunfowan & $+t$ & th & $t$ & $\$ \downarrow$ & $\$$ \\
\hline & Winter crops (winter what) & $t+1$ & tt & t to & $\downarrow \downarrow$ & $\uparrow$ \\
\hline & Irripatian nowds & na & $+10+$ & 4 & 44 & 4 \\
\hline & Ensoy crops & $\uparrow+1$ & $\uparrow$ & 1 & $\$ 4$ & $\downarrow$ \\
\hline & Uwestock & $+10+$ & 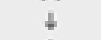 & $4+$ & $\$ 4$ & $\$$ \\
\hline & Marine tthented & tT & $t$ & na & 4 & na \\
\hline \multirow{4}{*}{$\begin{array}{l}\text { Eneroy and } \\
\text { traniport }\end{array}$} & Envrgy supply and distribution & $\dagger$ & $4 \dagger$ & $t$ & 4 & $\uparrow$ \\
\hline & Winter ensing demand & +4 & th & $t$ & tt & + \\
\hline & Summer energy demand & $\perp$ & $₫$ & $\Perp$ & 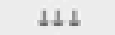 & 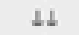 \\
\hline & Transport & $\dagger$ & 4 & 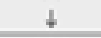 & + & $t$ \\
\hline \multirow{2}{*}{ Tourkm } & Winter (including sis] tourbm & † & 4 & 44 & t+t & 4 \\
\hline & Summer tourism & $\uparrow$ & $\uparrow \uparrow$ & $\uparrow$ & $\$ 4$ & $\uparrow$ \\
\hline \multirow{2}{*}{$\begin{array}{l}\text { Property } \\
\text { insurance }\end{array}$} & Flooding claims & $\pi$ & $4+$ & 44 & 27 & 77 \\
\hline & storms clains & $\div$ & $\$ 4$ & $\$+$ & $m$ & $m$ \\
\hline \multirow{6}{*}{ Human bealth } & Hoaturulasod mortalitymorbidty & $\downarrow$ & 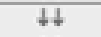 & $\downarrow+$ & $\$ 4$ & 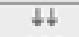 \\
\hline & Cob-rolsod mortilymoibidy & $\uparrow$ & $\uparrow \uparrow$ & $\uparrow \uparrow$ & $\uparrow$ & ttt \\
\hline & Health ettects of fooding & 4 & 4 & 44 & $\$ 4$ & $\$ 4$ \\
\hline & Woctor-borne disarses & 4 & 4 & 4 & 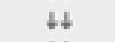 & $\$$ \\
\hline & Food salutyowatem bome diswass & 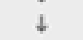 & 4 & 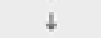 & $\$$ & $\$$ \\
\hline & Alople disass, dus to anculkrgens & 4 & 4 & 4 & 4 & 4 \\
\hline
\end{tabular}

One of the few studies which has systematically analyzed climate impacts in Europe is PESETA (Ciscar, 2009; Van Regemorter, 2011). Five impact categories were addressed: agriculture, river floods, coastal systems, tourism, and human health; with respect to two time horizons: the 2020s and 2080s (Note1). The EU was divided in five 
regions, including Northern Europe, British Isles, Central Europe North, Central Europe South, and Southern Europe. This last aggregation includes Portugal, Spain, Italy, Greece, and Bulgaria.

According to both PESETA and IPCC AR4, the Mediterranean region (MED henceforth) is a hotspot for the physical impacts of climate change (Note 2). From Table 1 it can be seen that MED will likely to be subject to increased water stress, droughts and wildfire; reduced summer tourism, reduced agricultural productivity, reduced hydropower; increased health risks from heat waves, increased summer energy demand, land loss in coastal zones. The region is expected to see a drop in precipitations of $25-30 \%$ by mid-century, with a wide variation around the mean. If rainfall on parts of the European side of MED should increase significantly, the region would become similar to the desert in the southern shore and extended wildfire would seriously threaten the forest, which currently cover parts of the region (Note 3 ).

PESETA estimates that, for agricultural yields, Southern Europe (SE) will experience already in 2020 a reduction, unlike the rest of the continent, where the estimated average gain is around $15 \%$. In 2080, the picture for SE is even gloomier, with a $25 \%$ loss in the hottest scenario. While river flooding should not affect SE, this will be the case for sea floods. In 2020 conditions for outdoor tourism will improve throughout Europe. The trend will continue in 2080 for the spring season, but in the summer touristic flows will head more towards the North at the expenses of the MED. SE, which now accounts for half total capacity of tourist accommodation, is projected to be the only region experiencing a decline in bed-nights. Finally, in 2020 without adaptation and acclimatization, heat waves could provoke a toll of 25,000 extra deaths, possibly higher in SE and in Central Europe South. This figure is poised to increase to 60,000 to 165,000 by 2080 .

In PESETA, the physical impacts are valued by means of a CGE model. It is estimated that, if the climate of 2080 would occur today, the annual damage of climate change to the EU economy, in terms of GDP loss, would be between 20 billion euros for the $2.5^{\circ} \mathrm{C}$ scenario and 65 billion euros for the $5.4^{\circ} \mathrm{C}$ scenario, with high sea level rise. Not surprisingly, these figures hide a high variation across regions, climate scenarios and impact categories.

In order to effectively design adaptation plans and response strategies, estimates of impacts at the national, and possibly regional and industrial level, are necessary. In September 2007, the Italian Ministry of the Environment organized a conference in Rome, to present and discuss available evidence of climate change impacts for Italy (Carraro, 2008). Results obtained with a CGE model, similar to the one used in PESETA, were presented there (Eboli et al., 2008). That model accounts for impacts on health, agriculture, tourism, energy demand, sea level rise and increased desertification. Over the period 2001-2050 the estimated annual loss of Italian GDP would be between $0.12-0.16 \%$ if temperature increases by $0.93^{\circ} \mathrm{C}$ (cumulatively $0.12-0.19 \%$ ) or between $0.16-0.20 \%$ if the increase would be $+1,2^{\circ} \mathrm{C}$ (cumulatively $0.20-0.38 \%$ ). This would translate into a welfare reduction, in 2050, of about 20-30 billions Euro at current prices.

This work presents new estimates of economic impacts of climate change for Italy, and compares them with those of some neighboring countries in the Mediterranean region. Quality of results is much superior to that of the previous estimates, for various reasons. First, instead of using a static CGE model, a full-fledged dynamic integrated assessment model, coupling a climate module with a sophisticated CGE framework, is used (Note 4). Second, the model runs, at different time intervals, up to the year 2100 , bringing about more accurate figures when future impacts are discounted at present time. Third, additional impacts are considered, notably those on water availability (obviously important for the MED) and heat effects on labor productivity (Note 5).

The paper is organized as follows. The next section describes the model structure and how different climate impacts have been introduced in it. Section 3 presents the results for Italy, whereas Section 4 compares them with those of other countries in the MED region, exploring also the distributional implications. A final section provides some concluding remarks.

\section{Model Structure: Impacts of Climate Change}

Estimations of climate change impacts presented in this paper have been obtained with a special version of the World Bank's ENVISAGE (ENVironmental Impact and Sustainability Applied General Equilibrium) Model (van der Mensbrugghe, 2008). Key characteristics of the model and dynamics are discussed in the Appendix.

ENVISAGE, which runs from a base year of 2004 through 2100, incorporates a wide set of impact (or damage) functions that considerably encompass the economy-wide effects of climate change (Note 6). Following Eboli, Parrado, and Roson (2010) the required parameters for the impacts are obtained from a number of different sources and specific micro-sectoral studies (Roson \& Sartori, 2010). Climate change impacts are introduced as exogenous parameter variations, affecting the general equilibrium in all time steps of the recursive dynamics. The impacts normally affect exogenous variables, like stocks of land and capital/infrastructure (e.g., in the case 
of sea level rise), or parameters, like factor or multi-factor productivity (e.g., in the case of agricultural yield). In a few instances, for example in energy demand changes due to varying needs for cooling/heating, impacts affect naturally endogenous variables, like household energy consumption, through shifting factors in the demand equations.

We consider here the following climate change impacts:

- $\quad$ Agricultural yields

- $\quad$ Sea level rise

- Water availability

- $\quad$ Tourist arrivals

- $\quad$ Energy demand (cooling / heating)

- $\quad$ Health effects

- $\quad$ Heat-related labor productivity

The current version of the model does not account for other impacts, such as effects of forestry, ecosystems and biodiversity, extreme weather and catastrophic events. We now describe how each impact has been modelled and how parameters have been estimated.

\subsection{Agriculture}

Variations in agricultural yield are modelled as changes in multifactor productivity for agricultural activities. Parameters were obtained through elaboration from data presented in the IPCC AR4 report (Easterling et al., 2007), where a meta-analysis can be found, summarizing results from many different studies. Central values for 1, 3 and 5 degrees changes were collected for three crops (maize, wheat, rice) and for high and low latitudes regions, to estimate parameters of a second-degree polynomial. Table 2 summarizes the central estimates for a three $3^{\circ} \mathrm{C}$ variation in local mean temperature, under the scenario "with adaptation" (Note 7).

Table 2. Estimates of yield changes for $3^{\circ} \mathrm{C}$ degrees changes in temperature

\begin{tabular}{ccc}
\hline & Mid-High Latitude & Low Latitude \\
\hline Maize & $2 \%$ & $-2 \%$ \\
Wheat & $18 \%$ & $-1 \%$ \\
Rice & $5 \%$ & $1 \%$ \\
\hline
\end{tabular}

Region-specific parameters for the impact function in this study were obtained through (i) a weighted average of crop functions, with weights given by the relative share of each crop in total regional output, as well as by the relative allocation of each region in the two areas (high and low latitudes), and (ii) by forcing the function to be zero for zero changes in temperature.

\subsection{Sea Level Rise}

Sea level rise is modelled through reductions in available stocks of capital and land. Parameters were estimated for a static CGE model (Bosello et al., 2007) from simulation results of the DIVA model, which is also used in the PESETA study (Vafeidis et al., 2008).

Although the effects of sea level can be dramatic in some specific areas, the amount of land and capital endowments lost in large regions, like those considered in the present study, is generally limited. Some exceptions are the Rest of East Asia (XEA) region, where about $0.87 \%$ of land and capital stocks are lost for $1{ }^{\circ} \mathrm{C}$ degree increase in temperature, and the Rest of South Asia (XSA), where the loss is restricted to $0.35 \%$.

\subsection{Water}

Water availability affects multifactor productivity (yield) in agriculture. It is assumed that changes in productivity depend on changes in Mean Annual Runoff (MAR) in each country, with effects depending on how much each region is constrained by its water resources. This is estimated on the basis of the current ratio between water demand and available surface water.

Data for MAR 2000, municipal and industrial demand, environmental flow requirements, and estimates of MAR 
2050 according to two different climate GCM models (a simple average of the two scenarios was used here), are taken from Strzepek and Boehlert (2009). For the regional aggregation used in this study, we estimate a strong negative effect of reduced water availability for the Middle East and North Africa (-8.13\% change in agriculture productivity for a one degree increase in temperature) and a positive effect for China (CHN), India (IND), and Sub-Saharan Africa (SSA).

\subsection{Tourism}

Changes in tourism flows, due to variations in climate conditions, are modelled as adjustments in international income transfers, to account for changes in the expenditure of incoming or outgoing tourists. Parameters for tourism have been derived from the Hamburg Tourism Model (Hamilton et al., 2005) as described in Berrittella, Bigano, Roson and Tol (2006). Positive income transfers are estimated for the United States (becoming, all else equal, a more attractive tourism destination), whereas negative effects are particularly felt in African countries.

\subsection{Energy Demand}

A model of household energy demand by fuel type has been estimated by DeCian, Lanzi and Roson (2007) using econometric techniques and a global panel data base. Energy demand is taken to depend, among other factors, on seasonal average temperatures. By increasing exogenous temperatures, in all seasons, by $1^{\circ} \mathrm{C}$, it is possible to estimate the implied (long-run) change in energy demand, for electricity, gas, and oil products consumption. For most of the regions, climate change is estimated to reduce total energy demand by households, as reduced warming needs more than compensate the increased cooling needs. However, some regions do experience an increase in energy demand. These are: Rest of East Asia (XEA), India (IND), Rest of South Asia (XSA) and Brazil (BRA).

\subsection{Human Health}

Bosello, Roson and Tol (2006) study the economic impacts of climate-induced change in human health, viz. cardiovascular and respiratory disorders, diarrhea, malaria, dengue fever and schistosomiasis. Changes in morbidity and mortality are interpreted as changes in labor productivity and demand for health care and are used to shock exogenous parameters in a CGE model including 16 regions. The same variations in labor productivity are used here and are applied to all countries inside the same macro-region.

Changes can be both positive and negative. Positive variations of labor productivity are expected when climate change reduces the incidence of some diseases, for example cold-related. Positive effects are estimated for China (CHN), Russia (RUS), and other regions. Negative and significant effects, however, are estimated for Sub-Saharan Africa (SSA), Middle East and North Africa (MNA), India (IND), Rest of South (XSA) and East (XEA) Asia, United States (USA) and Rest of the World (XLC).

\subsection{Labour Productivity}

We consider the ability to work under different climate conditions. Increased temperature and humidity reduce the labor productivity in a number of occupations, requiring open air activity. Kiellstrom, Kovats, Lloyd, Holt, and Tol (2008) estimate the direct impact of climate change on regional labor productivity. These results have been elaborated to get estimates of variations in labor productivity for $1{ }^{\circ} \mathrm{C}$ increase in temperature and for 10 macro-regions.

Variations of labor productivity are always negative and especially significant in China (CHN), India (IND) and in most developing countries, where the incidence of agriculture and other open-air activities is relatively larger.

\section{Simulation Results: Italy vs. Rest of the World}

We present the simulation results in terms of comparison between two scenarios: a business-as-usual case without climate change impacts, and a counter-factual case where impacts are included. In both settings policy interventions (related or unrelated to climate change) are not simulated, nor are technical changes and adaptation measures beyond substitution processes in production and consumption.

The exercise entails two simulation runs. First, a baseline is built by running the recursive dynamic model with endogenous capital accumulation and labor productivity, so that the model is forced to reproduce given (econometrically estimated) scenarios of economic growth for each region. Subsequently, holding labor productivity exogenous, climate change impacts are introduced, affecting equilibrium at all time steps, on the basis of the damage functions described above.

Temperature variations are endogenously estimated in ENVISAGE. The global average temperature is found to change in the $21 \mathrm{st}$ century by $4.87^{\circ} \mathrm{C}$, reduced to $4.79^{\circ} \mathrm{C}$ when climate impact feedbacks are taken into account. This figure is quite high if compared with those of the IPCC SRES scenarios $\left(1.79^{\circ} \mathrm{C}\right.$ for $\mathrm{B} 1,2.65^{\circ} \mathrm{C}$ for A1B, 
$3.13^{\circ} \mathrm{C}$ for A2), but consistent with the (upward revised) recent estimates of the MIT Integrated Global Systems Model, predicting an increase of $5.2^{\circ} \mathrm{C}$ with respect to pre-industrial temperature (Note 8).

Table 3 shows the variations in real GDP between the two scenarios (with and without climate change), for all regions in the model, at a 10-years interval, from 2010 up to 2100 . The regions which appear to be most damaged by climate change are the developing ones: Rest of East Asia (XEA), Middle East and North Africa (MNA), Sub-Saharan Africa (SSA), Rest of the World (XLC), Rest of South Asia (XSA), Brazil (BRA), India (IND) and China (CHN). Roson and van der Mensbrugghe (2012) provide a discussion on these results, underlying driving factors and policy implications.

Table 3. Deviations in regional real GDP

\begin{tabular}{|c|c|c|c|c|c|c|c|c|c|c|}
\hline & 2010 & 2020 & 2030 & 2040 & 2050 & 2060 & 2070 & 2080 & 2090 & 2100 \\
\hline $\mathrm{CHN}$ & $-0,03 \%$ & $-0,56 \%$ & $-0,41 \%$ & $-0,44 \%$ & $-0,93 \%$ & $-1,14 \%$ & $-1,49 \%$ & $-2,13 \%$ & $-3,02 \%$ & $-4,13 \%$ \\
\hline JPN & $-0,02 \%$ & $-0,10 \%$ & $-0,11 \%$ & $-0,14 \%$ & $-0,18 \%$ & $-0,14 \%$ & $-0,11 \%$ & $-0,05 \%$ & $0,03 \%$ & $0,13 \%$ \\
\hline XEA & $-2,05 \%$ & $-5,89 \%$ & $-7,30 \%$ & $-8,71 \%$ & $-10,20 \%$ & $-10,36 \%$ & $-10,77 \%$ & $-11,44 \%$ & $-12,35 \%$ & $-13,47 \%$ \\
\hline IND & $0,71 \%$ & $0,17 \%$ & $0,05 \%$ & $-0,29 \%$ & $-1,08 \%$ & $-1,23 \%$ & $-1,67 \%$ & $-2,48 \%$ & $-3,65 \%$ & $-5,21 \%$ \\
\hline XSA & $0,30 \%$ & $-0,46 \%$ & $-0,90 \%$ & $-1,65 \%$ & $-2,63 \%$ & $-2,85 \%$ & $-3,39 \%$ & $-4,25 \%$ & $-5,38 \%$ & $-6,76 \%$ \\
\hline CAN & $0,68 \%$ & $1,89 \%$ & $2,80 \%$ & $3,59 \%$ & $4,22 \%$ & $4,44 \%$ & $4,13 \%$ & $3,24 \%$ & $1,67 \%$ & $-0,70 \%$ \\
\hline USA & $-0,07 \%$ & $-0,23 \%$ & $-0,22 \%$ & $-0,24 \%$ & $-0,26 \%$ & $-0,07 \%$ & $-0,01 \%$ & $-0,09 \%$ & $-0,35 \%$ & $-0,86 \%$ \\
\hline BRA & $-0,52 \%$ & $-1,69 \%$ & $-2,23 \%$ & $-2,85 \%$ & $-3,53 \%$ & $-3,67 \%$ & $-3,87 \%$ & $-4,21 \%$ & $-4,78 \%$ & $-5,61 \%$ \\
\hline FRA & $0,33 \%$ & $0,58 \%$ & $0,64 \%$ & $0,70 \%$ & $0,79 \%$ & $0,81 \%$ & $0,77 \%$ & $0,68 \%$ & $0,51 \%$ & $0,29 \%$ \\
\hline DEU & $0,20 \%$ & $0,40 \%$ & $0,48 \%$ & $0,57 \%$ & $0,72 \%$ & $0,82 \%$ & $0,97 \%$ & $1,15 \%$ & $1,39 \%$ & $1,73 \%$ \\
\hline ITA & $0,14 \%$ & $0,10 \%$ & $-0,05 \%$ & $-0,19 \%$ & $-0,31 \%$ & $-0,42 \%$ & $-0,51 \%$ & $-0,55 \%$ & $-0,51 \%$ & $-0,35 \%$ \\
\hline ESP & $0,01 \%$ & $-0,20 \%$ & $-0,56 \%$ & $-0,86 \%$ & $-1,11 \%$ & $-1,33 \%$ & $-1,48 \%$ & $-1,56 \%$ & $-1,52 \%$ & $-1,33 \%$ \\
\hline GBR & $0,18 \%$ & $0,38 \%$ & $0,50 \%$ & $0,62 \%$ & $0,76 \%$ & $0,88 \%$ & $1,02 \%$ & $1,22 \%$ & $1,48 \%$ & $1,87 \%$ \\
\hline RUS & $1,22 \%$ & $3,63 \%$ & $4,08 \%$ & $4,20 \%$ & $4,14 \%$ & $4,03 \%$ & $3,88 \%$ & $3,67 \%$ & $3,37 \%$ & $2,98 \%$ \\
\hline XEC & $1,15 \%$ & $1,18 \%$ & $0,74 \%$ & $0,26 \%$ & $-0,30 \%$ & $-0,50 \%$ & $-0,87 \%$ & $-1,47 \%$ & $-2,30 \%$ & $-3,39 \%$ \\
\hline REU & $0,31 \%$ & $0,56 \%$ & $0,58 \%$ & $0,60 \%$ & $0,61 \%$ & $0,62 \%$ & $0,64 \%$ & $0,70 \%$ & $0,84 \%$ & $1,11 \%$ \\
\hline SSA & $-0,66 \%$ & $-3,34 \%$ & $-4,67 \%$ & $-5,67 \%$ & $-6,57 \%$ & $-6,41 \%$ & $-6,57 \%$ & $-7,10 \%$ & $-8,01 \%$ & $-9,22 \%$ \\
\hline MNA & $-0,87 \%$ & $-2,91 \%$ & $-3,90 \%$ & $-5,05 \%$ & $-6,38 \%$ & $-6,89 \%$ & $-7,54 \%$ & $-8,28 \%$ & $-9,02 \%$ & $-9,58 \%$ \\
\hline RHY & $-0,07 \%$ & $-0,42 \%$ & $-0,58 \%$ & $-0,74 \%$ & $-0,86 \%$ & $-0,79 \%$ & $-0,74 \%$ & $-0,72 \%$ & $-0,78 \%$ & $-0,90 \%$ \\
\hline XLC & $-1,01 \%$ & $-3,12 \%$ & $-4,17 \%$ & $-5,22 \%$ & $-6,25 \%$ & $-6,42 \%$ & $-6,70 \%$ & $-7,16 \%$ & $-7,80 \%$ & $-8,61 \%$ \\
\hline
\end{tabular}

At a global scale, European countries do not perform badly. Some countries actually benefit from the climate change, particularly the northern ones (Germany, Great Britain and, to a smaller extent, France), whereas Mediterranean countries - Italy and Spain -are negatively affected. Figure 1 provides a graphical representation of changes in real GDP in Europe, highlighting the non-linear effects over time.

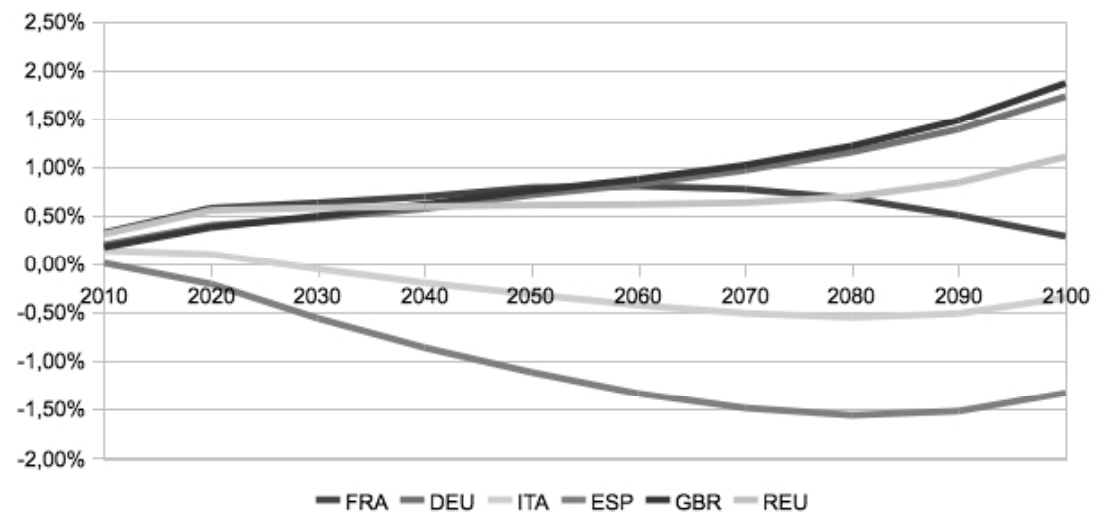

Figure 1. Deviations in regional real GDP of EU countries

Eboli, Parrado and Roson (2008) conducted a similar exercise using a static CGE model (applied only at 2050) and exogenous climate scenarios (Note 9). Those authors estimated a fall in real GDP for Italy, at 2050, of about 
$0.12-0.16 \%$, depending on the climate scenario. As seen in Table 3 the estimated reduction at 2050 stemming from the ENVISAGE model is $-0.31 \%$, which is consistent with the much higher mean temperature variation (Note 10). Eboli, Parrado and Roson (ibid.) also provided estimates of the annualized impact over the whole century. However, having only one observation point (2050), they simply assumed that the damage evolved quadratically or exponentially. In the present ENVISAGE simulation exercise we can instead trace the variation at a much finer scale, allowing us to get a much more precise estimate (Note 11).

Table 4 presents the annualized damage in Italian real GDP obtained in the two studies, with $1 \%$ and $3 \%$ discount rates. Results from Eboli, Parrado and Roson are kept distinct for the two climate scenarios, but averaged for the two cases of quadratic and exponential growth.

Table 4. Annualized impacts on Italian real GDP

\begin{tabular}{ccc}
\hline & $1 \%$ Discount rate & $3 \%$ Discount rate \\
\hline Eboli, Parrado and Roson (2008) - B1 Scenario & $0.18 \%$ & $0.13 \%$ \\
Eboli, Parrado and Roson (2008) - A2 Scenario & $0.37 \%$ & $0.21 \%$ \\
This study & $0.18 \%$ & $0.07 \%$ \\
\hline
\end{tabular}

Despite the higher values for the year 2050, this study produces lower estimates for the climate change impacts in terms of real GDP. This is due to the much different time profile, with some gains for the Italian economy at the beginning of the century, followed by losses, rising, however, less than exponentially. This implies lower annualized values, particularly when high discount rates are adopted.

By running model simulations with a subset of exogenous shocks, it is possible to decompose the contribution of each factor to the overall result. Figure 2 shows the variation of Italian real GDP in 2050 and 2100, obtained by assessing, in different simulations, the effects of impacts in energy demand, sea level rise, tourism, agriculture (including water) and labor productivity (including health).

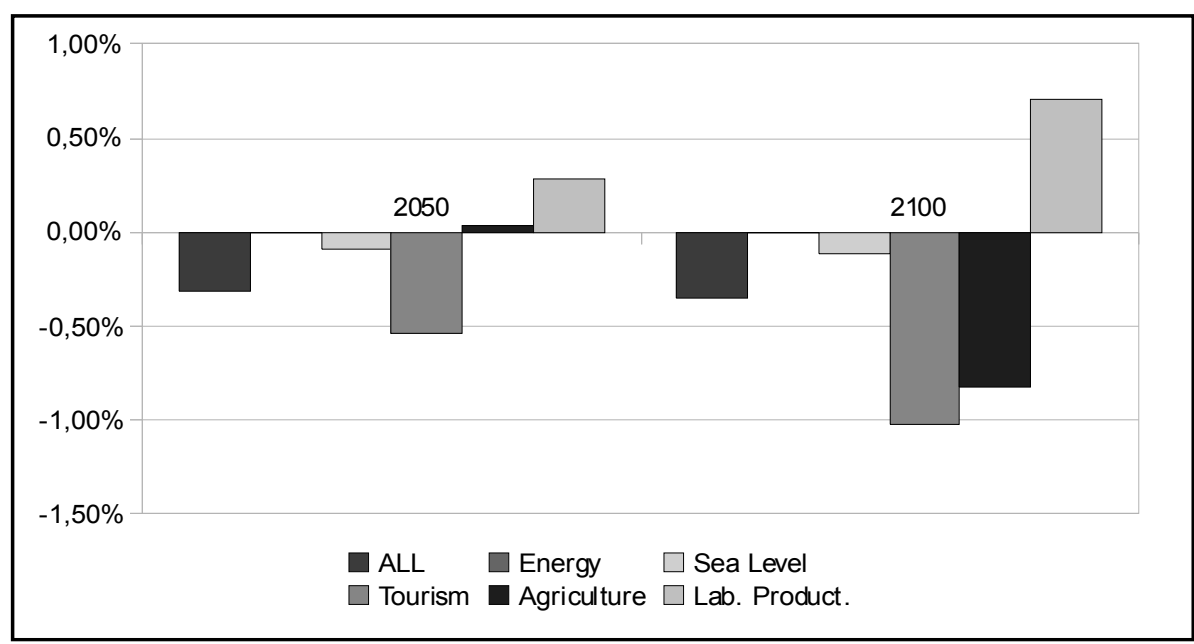

Figure 2. Decomposition of effects for Italian real GDP

The first bar indicates the overall deviation in real GDP as in Table 3. The second bar, which actually cannot be distinguished, would show the variations in real GDP induced solely by changes in the consumption demand for energy. The third bar highlights the contribution of land and capital losses due to sea level rise. The fourth bar shows the tourism impacts. As a consequence of climate change, Italy is expected to lose some attractiveness as a tourist destination. Given the share of tourism in the national economy, the impact is quite significant and negative, contributing to more than $-1 \%$ of real GDP in 2100 . The fifth bar refers to agriculture impacts, including variations in yield for different climate conditions and varying water availability. Interestingly, it is the only type of impact whose sign changes during the century. It is known that limited increases of carbon dioxide concentrations in the atmosphere may generate a fertilization effect, although there is no general consensus about 
how relevant this effect may be. For higher GHG concentrations and temperatures, however, yields are diminished and more water is needed. Unfortunately, most regional climate models predict significant reductions of precipitations in the Mediterranean basin. This explains why, by the end of the century, agricultural impacts on real GDP, despite the quite low share of the agricultural sector in the Italian economy, are large and negative. The sixth bar refers to impacts on labor productivity, including variations in working hours due to health conditions and direct effects of heat on labor productivity. The latter effect is very small for Italy, whereas it is one of the main impact factors in developing countries. Health effects are related to changing incidence of cold-related, heat-related and vector-borne diseases. Again, the latter class is irrelevant for Italy. It turns out that the reduction of cold-related diseases more than compensate the increase in heat-related diseases in the labor force, which amounts to an increase in labor productivity and real income.

In addition to results in terms of GDP, ENVISAGE produces results about industrial production volumes, relative prices, trade flows, consumption patterns, and several other variables. It may be interesting to see how the productive structure of the Italian economy is supposed to vary. Figure 3 plots the changes in industrial production volumes for the two reference years 2050 and 2100.

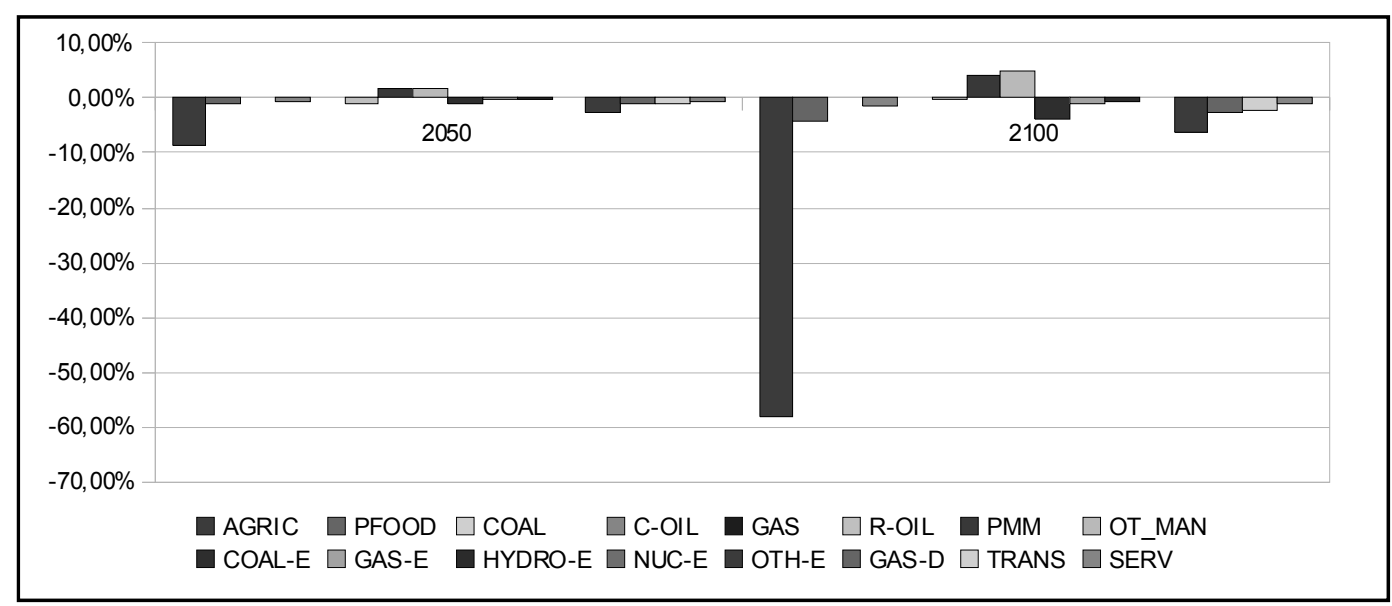

Figure 3. Changes in industrial production volumes -Italy $(2050,2100)$

The most dramatic effect is felt in agriculture, with physical production volumes dropping by more than $50 \%$ by the end of the century. This effect was not highlighted in the Eboli, Parrado, and Roson (2008), as that study stopped at 2050 and considered only mild gains in agricultural productivity. The findings for other industries are more similar. Both studies predict lower production volumes for energy and service industries, and some increases for manufacturing. Energy production is lower because of lower demand. On the other hand, falling agricultural production is likely to be accompanied by rising imports of foods, to be paid through additional exports of manufactured goods. In turn, this is made possible by a real devaluation, reducing purchasing power and production in non-traded services.

\section{Simulation Results: Italy vs. Rest of the Mediterranean}

How Italy would score, in comparison with other Mediterranean countries? We contrast here results for Italy with results obtained for two other regions: Spain, a country similar to Italy in terms of development and representative of Northern Mediterranean, and Middle East - North Africa (MENA), a composite aggregate of countries, representative of Southern Mediterranean (Note 12).

The variation in the real GDP in 2050 and 2100 of Spain is broadly similar to that of Italy, in terms of structure, although some differences can be noted. If we look at the sign of the changes in the various impacts for Spain in Figure 4 we notice that sea level rise effects are nearly absent. Another relevant difference refers to agriculture: the GDP change due to this effect is negative both in 2050 and in 2100 and quite sizeable at the end of the century. This impact is responsible for an overall negative impact of climate change that is larger for Spain than for Italy. 


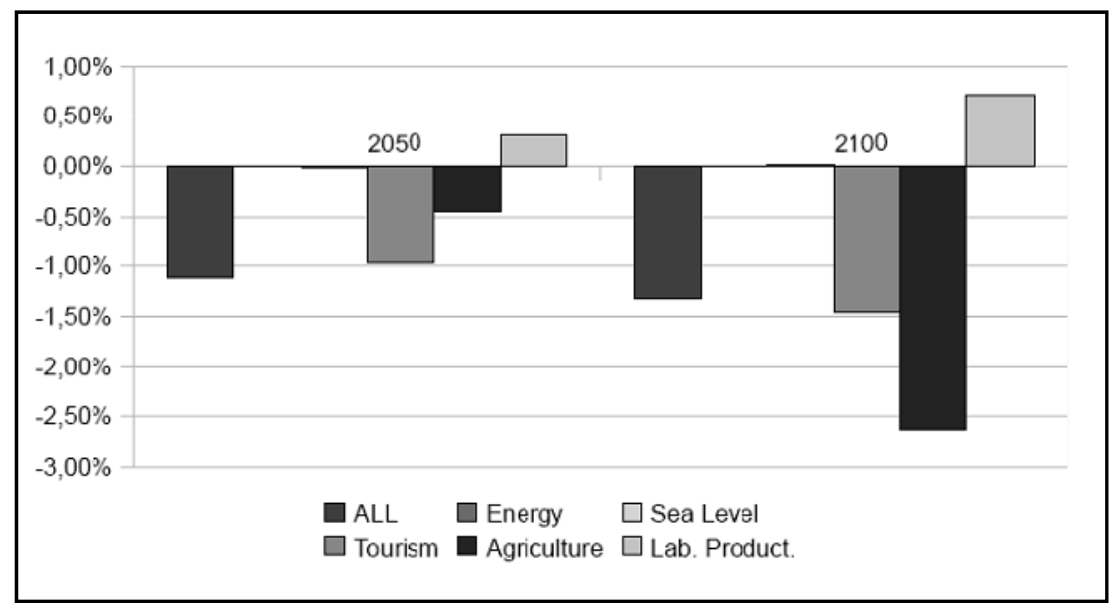

Figure 4. Decomposition of effects for Spanish real GDP

For MENA, the overall loss in real GDP is about six-fold in 2050 and nine-fold in 2100 relative to Spain. These proportions should be further multiplied by a factor three, if comparison is made with Italy (see Table 3 ). Thus impacts of climate change are much more severe on the southern shore of the Mediterranean, confirming that much of the (economic) burden of climate change is likely to be felt on developing countries. In the MENA region, individual impacts on GDP are all negative: in addition to a negative effect on agriculture, the most serious impact is on labour productivity, but also sea level rise and tourism contribute to the drop in GDP.

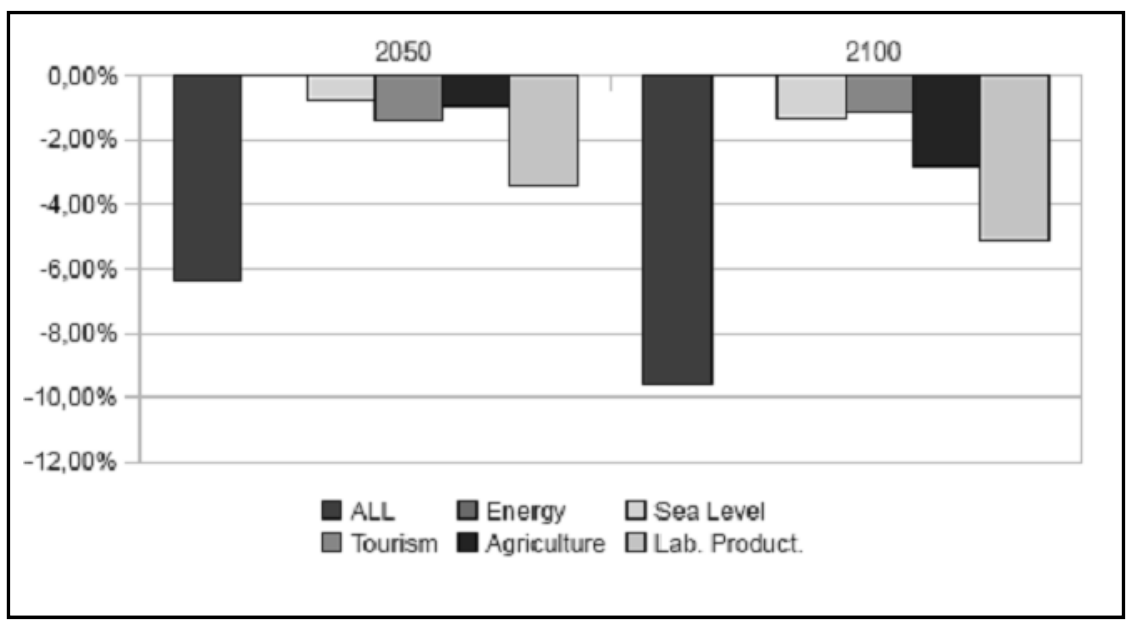

Figure 5. Decomposition of effects for Mena real GDP

These results suggest that climate change will create serious distributional issues in the world, with broader income differences between rich and poor countries (in the Mediterranean, between northern and southern countries). To highlight this aspect, we took results from simulations with ENVISAGE to build Gini indices of inequality for some groups of countries (Note 13). Figure 6 present plots of these indices over time (Note 14).

For the Mediterranean, the Gini index steadily grows, confirming the widening of per-capita income differentials in the area. The evolution of the Mediterranean index looks quite similar to the American one. Interestingly, the analogous index built for the European Union display little growth at the beginning of the century, but later it increases in a more than proportional way, whereas no significant distributional effects are detected for Europe at large. Therefore, climate change is expected to widen income differences between southern and northern Mediterranean, as well as between South and North Europe, but some convergence in income levels between Eastern and Western Europe is also expected. 


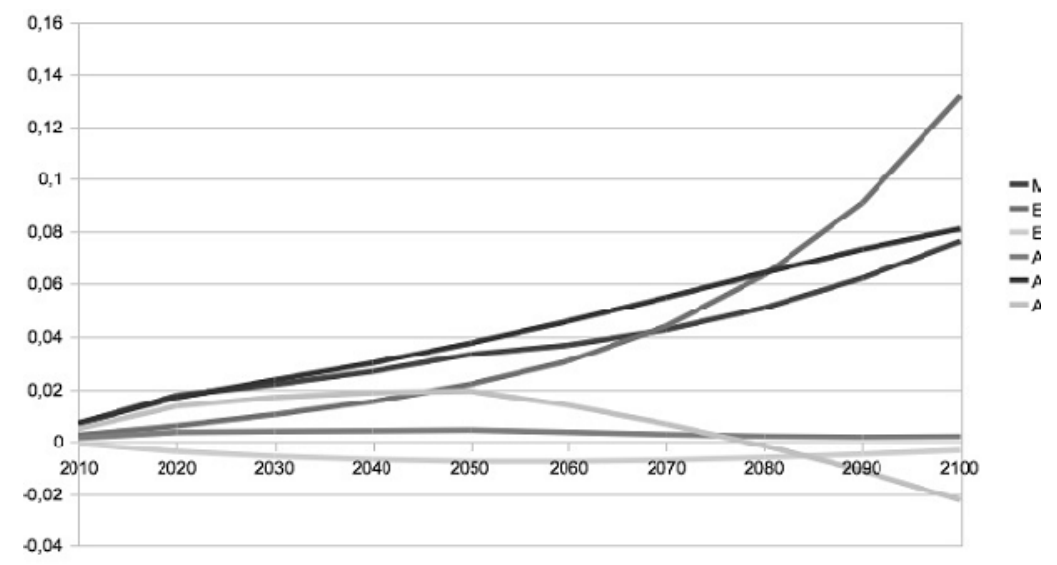

Figure 6. Time evolution of a Gini index for groups of countries

Even for Spain and MENA it is possible to analyze how the productive structure of these economies would be changed by climate change impacts. Figures 10 and 11 are analogous to Figure 3 and display variations in industrial production volumes for 2050 and 2100. As it was the case for Italy, the most dramatic effect is felt in agriculture, with physical production volumes dropping by almost $80 \%$ by the end of the century. Interestingly, Spain is quantitatively similar to MENA as far as this impact is concerned, instead of Italy. The other similarity worth pointing out between Spain and MENA is the loss of food production, unlike Italy. Finally, almost all production sectors in MENA appear to be adversely affected by climate change in a non-negligible way, with the exception of other manufacturing production and services.

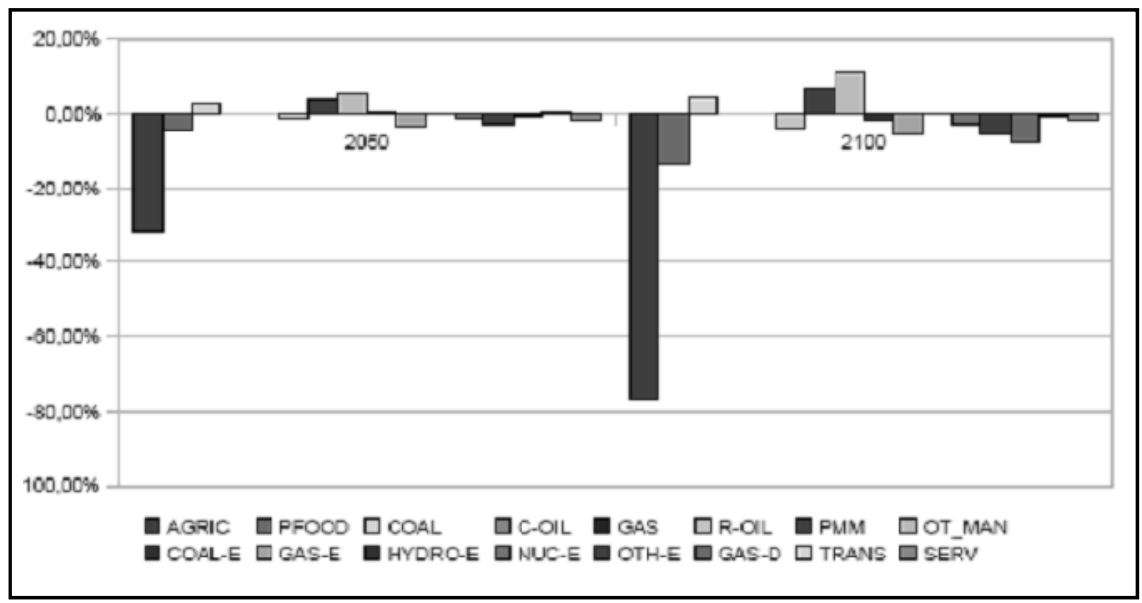

Figure 7. Chang in industrial production volumes Spain $(2050,2100)$ 


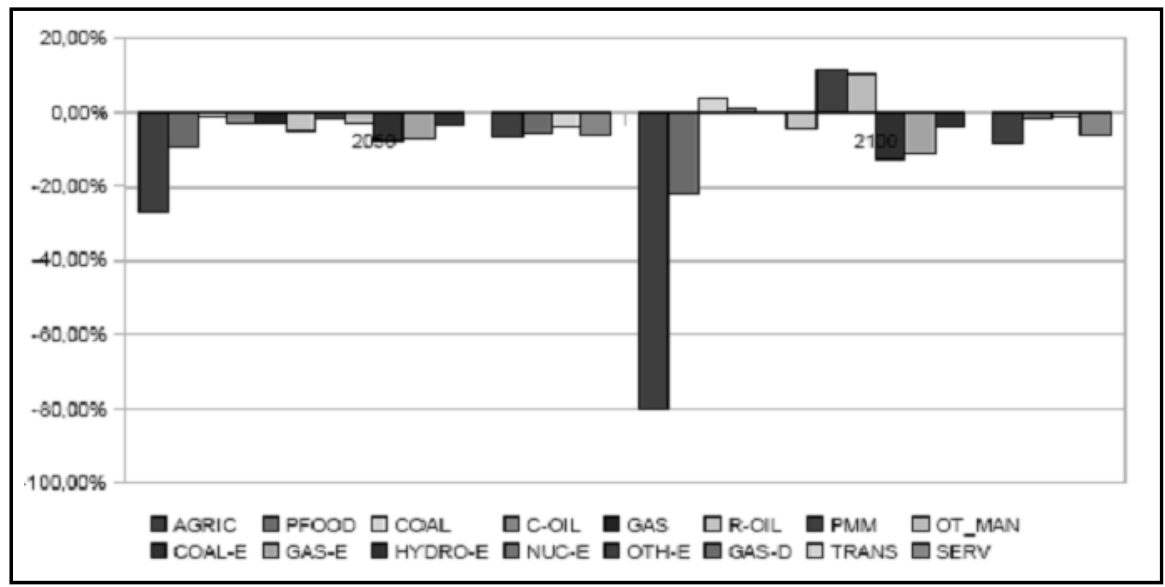

Figure 8. Change in industrial production volumes $\operatorname{MENA}(2050,2100)$

\section{Concluding Remarks}

This study presented new estimates of economic impacts of climate change for Italy and other countries, obtained with a full-fledged Integrated Assessment Model (ENVISAGE), developed at the World Bank. This model is qualitatively superior to other models used in the past for the same purpose, in particular to the model used by Eboli, Parrado and Roson (2008), who carried out a similar exercise. We found out that climate change is expected to reduce the Italian GDP in 2050 , with respect to a reference baseline, by $-0.31 \%$. This figure is about two times higher than the one estimated by Eboli, Parrado and Roson. However, as the drop in GDP, in percentage terms, does not increase significantly over time, annualized GDP losses are lower in this study.

Declining tourism demand is the main driver of the negative effect on GDP, as Italy would become less attractive as a tourist destination. By the end of the century, however, Italy would also experience severe losses in agricultural production, due to increased temperature and reduced water availability.

Even if Italy will notably be affected by climate change, in the absence of any mitigation or adaptation effort, other countries in the Mediterranean will experience larger economic impacts. This is the case of Spain, where losses in agriculture would be pronounced, but much more so this would be the case of Middle East and countries of the southern shore of the Mediterranean. The latter countries, as other developing countries in the world, are likely to suffer huge losses. Without active climate policies, income differentials will widen in the Mediterranean, but also within the European Union.

\section{References}

Berrittella, M., Bigano, A., Roson, R., \& Tol RSJ. (2006). A General Equilibrium Analysis of Climate Change Impacts on Tourism. Tourism Management, 25, 913-924. http://dx.doi.org/10.1016/j.tourman.2005.05.002

Bosello, F., Roson, R., \& Tol RSJ. (2006). Economy Wide Estimates of the Implications of Climate Change: Human Health. Ecological Economics, 58, 579-591. http://dx.doi.org/10.1016/j.ecolecon.2005.07.032

Bosello, F., Roson, R., \& Tol RSJ. (2007). Economy Wide Estimates of the Implications of Climate Change: Sea Level Rise. Environmental and Resource Economics, 37, 549-571. http://dx.doi.org/10.1007/s10640-006-9048-5

Carraro, C. (2008). Impatti dei cambiamenti climatici e strategie di adattamento in Italia. Il Mulino, Bologna: Una valutazione economica.

Ciscar, J. C. (2009). Climate Change Impacts in Europe - Final Report of the PESETA Research Project, JRC Scientific and Technical Reports EUR 24093 EN.

Cline, W. (2007). Global Warming and Agriculture: Impact Estimates by Country. Center for Global Development and Peterson Institute for International Economics, Washington DC.

De Cian, E., Lanzi, E., \& Roson, R. (2007). The Impact of Temperature Change on Energy Demand: A Dynamic Panel Analysis. FEEM Working Paper N.46.2007.

Easterling, W. E., Aggarwal, P. K., Batima, P., Brander, K. M., Erda, L., Howden, S., ... Tubiello, F. N. (2007). Food, Fibre and Forest Products. In Parry, M. L., Canziani, O. F., Palutikof, J. P., van der Linden, P. J., \& 
Hanson, C. E. (Eds.), Climate Change 2007: Impacts, Adaptation and Vulnerability (pp. 273-313). Contribution of Working Group II to the Fourth Assessment Report of the Intergovernmental Panel on Climate, Cambridge University Press, Cambridge.

Eboli, F., Parrado, R., \& Roson, R. (2008). Gli impatti macroeconomici del cambiamento climatico in Italia. Un'analisi di equilibrio generale. In Carraro, C. (Ed.), Impatti dei cambiamenti climatici e strategie di adattamento in Italia. Il Mulino, Bologna: Una valutazione economica.

Eboli, F., Parrado, R., \& Roson, R. (2010). Climate Change Feedback on Economic Growth: Explorations with a Dynamic General Equilibrium Model. Environment and Development Economics, 15, 515-533. http://dx.doi.org/10.1017/S1355770X10000252

Hamilton, J. M., Maddison, D. J., \& Tol RSJ. (2005). Effects of Climate Change on International Tourism. Climate Research, 29, 245-254. http://dx.doi.org/10.3354/cr029245

International Monetary Fund (IMF). (2007). Balance of Payments and International Investment Position Statistics, Washington D.C.

Kiellstrom, T., Kovats, R. S., Lloyd, S. J., Holt, T., \& Tol RSJ. (2008). The Direct Impact of Climate Change on Regional Labor Productivity, ENSEMBLES Project, Deliverable D7.8, European Commission, VI Framework Programme.

Parry, M. L., Canziani, O. F., Palutikof, J. P., van der Linden, P. J., \& Hanson, C. E. (2007). Climate Change 2007: Impacts, Adaptation and Vulnerability. Contribution of Working Group II to the Fourth Assessment Report of the Intergovernmental Panel on Climate, Cambridge: Cambridge University Press.

Roson, R., \& Sartori, M. (2010). The ENVironmental Impact and Sustainability Applied General Equilibrium (ENVISAGE) Model. Introducing Climate Changes Impacts and Adaptation. Changes in the Model Structure and Parameter Estimation. The World Bank, Mimeo.

Roson, R., \& van der Mensbrugghe, D. (2012). Climate Change and Economic Growth: Impacts and Interactions. International Journal of Sustainable Economy, forthcoming.

Strzepek, K., \& Boehlert, B. (2009). Competition for Water for the Food System. Mimeo.

Vafeidis, A. T., Nicholls, R. J., McFadden, L., Tol, R. S. J., Hinkel, J., Spencer, T., ... Klein, R. J. T. (2008). A New Global Coastal Database for Impact and Vulnerability Analysis to Sea-Level Rise. Journal of Coastal Research, 24, 917-924. http://dx.doi.org/10.2112/06-0725.1

van der Mensbrugghe, D. (2008). The ENVironmental Impact and Sustainability Applied General Equilibrium (ENVISAGE) Model. The World Bank, Mimeo.

Van Regemorter, D. (2011). Integrating Economic Impacts of Climate Change in a General Equilibrium Setup: The Case of Europe. Paper presented at the 2011 EAERE Conference, Rome June 29-July 2, 2011.

\section{Notes}

Note 1. The study did not consider other key impacts, such as effects of forestry, ecosystems and biodiversity, and catastrophic events.

Note 2. Indeed, the chapter on Europe of the Fifth Assessment Report due to come out in 2013 will mainly focus on MED, recognized as an especially vulnerable region.

Note 3. It is for these reasons that representatives of seventeen MED countries met near Athens on October 22nd, 2010 to establish the Mediterranean Climate Change Initiative (MCCI), whereby they pledged to work for "low-carbon, resource-efficient and climate-resilient" economies.

Note 4. A complete description of the model features is beyond the scope of the paper (see van der Mensbrugghe, 2008). Notable characteristics of the CGE sub-model are: AIDADS demand system, capital vintages and limited physical capital mobility, consistency with short and long run econometric projections of macroeconomic aggregates.

Note 5. On the other hand, desertification is not considered here. However, it was included in a rather grossly way in the previous national study.

Note 6. Even though the climate related impacts are typically referred to as damage functions, there are sectors, regions and time periods for which climate impacts are positive and not negative. For example, longer growing seasons in the northern and southern latitudes will have positive impacts, and a reduction in the demand for heat 
would also be seen as positive.

Note 7. At present, estimates of climate change on agricultural productivity vary considerably, depending on many specific assumption (see, e.g., Cline, 2007). For this reason, we prefer to rely on meta-analyses, encompassing a wide range of models and approaches.

Note 8. See http:// globalchange.mit.edu/igsm/.

Note 9. Assumptions about climate change were based on the IPCC SRES scenarios A2 and B1, forecasting a change in mean temperature over the period $2001-2050$ of $1.2^{\circ} \mathrm{C}$ and $0.93^{\circ} \mathrm{C}$ respectively.

Note 10 Results are much more divergent for other countries. For example, a gain was predicted for China and India, whereas simulations with the ENVISAGE model predict a loss. This is due to a very different modeling of impacts in agriculture, as well as to the inclusion of effects on water availability and direct impacts on labor productivity.

Note 11. Original results are at a one year interval up to 2015, five years up to 2050, ten years afterwards.

Note 12. Ideally, one would like to make a comparison between Italy and all countries in the Mediterranean. Available data and the model disaggregation scale do not allow us to make such a country-level analysis, though.

Note 13. A Gini index applied to an income distribution would be zero if all individuals in the sample have the same per-capita income. In other cases, the wider income variations are, the higher the index will be.

Note 14. Acronyms as follows: MED Mediterranean, EU European Union, EUR Europe at large, ASI Asia, AME America, AFR Africa.

Note 15. A detailed description is given in van der Mensbrugghe (2008).

\section{Appendix: A Cursory Description of the ENVISAGE Model}

The results in this paper rely on the World Bank's Environmental Impact and Sustainability Applied General Equilibrium (ENVISAGE) Model (Note 15). The ENVISAGE model's core is a relatively standard recursive dynamic global general equilibrium (CGE) model. Incorporated with the core CGE model is a greenhouse gas (GHG) emissions module that is connected to a simple climate module that converts emissions into atmospheric concentrations, radiative forcing and changes in mean global temperature. The climate module has feedback on the economic model through so-called damage functions, affecting a number of parameters in the model. The combination of the socio-economic CGE model with the climate module is commonly referred to an integrated assessment model (IAM).

ENVISAGE is calibrated to Release 7.1 of the GTAP dataset with a 2004 base year. It has been used to simulate dynamic scenarios through 2100 . The 112 countries/regions and 57 sectors of GTAP are aggregated to a smaller set of countries/regions and sectors to facilitate computing. In the current version of the present study the model is run under the regional and sectoral breakdown presented in the table below.

The GTAP data is supplemented with satellite accounts that include emissions of the so-called Kyoto gases - carbon dioxide $\left(\mathrm{CO}_{2}\right)$, methane $\left(\mathrm{CH}_{4}\right)$, nitrous oxide $\left(\mathrm{N}_{2} \mathrm{O}\right)$ and hydrofluorocarbons (F-gases), different electricity production activities (coal, oil and gas, hydro, nuclear and other), and potential land and hydro supplies.

Within each time period a full equilibrium is achieved given the fixed regional endowments, technology and consumer preferences. Production is modelled as a series of nested constant-elasticity-of-substitution (CES) functions that are designed to reflect the substitution and complementarity of inputs. Unlike many standard models, energy plays a key role as an input and is modelled as a complement to capital in the short-run but a substitute to capital in the long run. This reflects the putty/clay specification of production that incorporates vintage capital. The key assumption is that there is greater substitution across inputs in the long run (i.e. with new capital) than in the short run (with old or installed) capital. One consequence of this specification is that countries that have higher growth and higher rates of investment typically have a more flexible economy in the aggregate. There is a single representative household that consumes goods and services, and saves. The saving rate is partially a function of the demographic structure of the region. Savings rise as either the elderly or youth dependency ratios fall. Investment is savings driven. Aggregate public expenditures are typically fixed as a share of total GDP and revenues adjust to maintain fiscal balance (through a lump sum tax on households). Other model closures for the public sector are possible. 
Table A1. Regional and industrial disaggregation of ENVISAGE model (version used here)

\begin{tabular}{|c|c|c|c|}
\hline Acronym & Region & Acronym & Industry \\
\hline $\mathrm{CHN}$ & China & AGRIC & Agriculture \\
\hline JPN & Japan & PFOOD & Processed Food \\
\hline XEA & Rest of East Asia & COAL & Coal \\
\hline IND & India & C-OIL & Crude Oil \\
\hline XSA & Rest of South Asia & GAS & Gas \\
\hline CAN & Canada & R-OIL & Refined Oil \\
\hline USA & United States & PMM & Paper, Minerals and Metals \\
\hline BRA & Brazil & OT_MAN & Other Manufacturing \\
\hline FRA & France & COAL-E & Coal Energy \\
\hline DEU & Germany & GAS-E & Gas Energy \\
\hline ITA & Italy & HYDRO-E & Hydro Energy \\
\hline ESP & Spain & NUC-E & Nuclear Energy \\
\hline GBR & Great Britain & OTH-E & Other Sources Energy \\
\hline RUS & Russia & GAS-D & Gas Distribution \\
\hline $\mathrm{XEC}$ & Rest of Europe & TRANS & Transportation \\
\hline REU & Rest of European Union & SERV & Services \\
\hline SSA & Sub-Saharan Africa & & \\
\hline MNA & Middle East and North Africa & & \\
\hline RHY & Rest of High Income (Annex I) Countries & & \\
\hline XLC & Rest of the World & & \\
\hline
\end{tabular}

Aggregate demand by sector is summed across all domestic agents and represents a composite of domestically produced goods and imports - the so-called Armington aggregate. The aggregate Armington good is allocated between domestic production and imports using a two-nested CES specification. The first nest allocates aggregate demand between domestic production and an aggregate import bundle. The second nest decomposes aggregate imports into import by region of origin. This generates a bilateral trade flow matrix. Domestic producers are assumed to supply both domestic and export markets without friction, i.e. the law of one price holds for domestically produced goods irrespective of their final destination. Bilateral trade is associated with three price wedges. The first wedge reflects differences between producer prices and the border (FOB) price, i.e. an export tax or subsidy. The second wedge reflects international trade and transport margins, i.e. the difference between FOB and CIF prices. The third wedge reflects the difference between the CIF price and the end-user price, i.e. import tariffs. All three wedges are fully bilateral.

Model closure is consistent with long-term equilibrium. As stated above, fiscal balance is typically maintained through lump sum taxes on households under the assumption of fixed public expenditures (relative to GDP). Changes in revenues, for example carbon tax revenues, imply a net decrease in household direct taxes. Investment is savings driven. This assumption implies that changes in investment are likely to be relatively 
minor since public and foreign savings are fixed and household savings will be relatively stable relative to income. The third closure rule is that the capital account is balanced. Ex ante changes in the trade balance are therefore offset through real exchange rate effects. A positive rise in net transfers, for example through a cap and trade scheme, would tend to lead to a real exchange rate appreciation.

The model dynamics are relatively straightforward. Population and labor force growth rates are based on the UN population's projection - with the growth in the labor force equated to the growth of the working age population (15-64). Investment, as mentioned above, is savings driven and the latter is partially influenced by demographics. Productivity growth in the baseline is 'calibrated' to achieve a target growth path for per capita incomes — differentiated for agriculture, manufacturing and services.

Emissions of GHGs have three drivers. Most are generated through consumption of goods-either in intermediate of final demand-for example the combustion of fossil fuels. Some are driven by the level of factor input - for example methane produced by rice is linked to the amount of cultivated land. And the remainder is generated by aggregate output-for example waste-based methane emissions. The climate module takes as inputs emissions of GHGs and converts them to atmospheric concentration, then radiative forcing and finally temperature change. The temperature change is linked back to the socio-economic model through damage functions. 